\title{
Efektivitas model pembelajaran kooperatif tipe teams games tournaments (TGT) terhadap hasil belajar matematika siswa kelas VII SMP Negeri 3 Kempo
}

\section{Yoniar Puspita Dewi ${ }^{*}$, Nyoman Sridana ${ }^{2}$, Baidowi $^{2}$, Sripatmi $^{2}$}

${ }^{1}$ Mahasiswa Pendidikan Matematika, FKIP, Universitas Mataram, Mataram

${ }_{2}^{2}$ Pendidikan Matematika, FKIP, Universitas Mataram, Mataram

yuniarpuspita333@gmail.com

Diterima: 11 Juni 2021; Direvisi: 30 Juni 2021; Dipublikasi: 30 Juni 2021

\begin{abstract}
This research aims to determine the effectiveness of the Teams Games Tournaments (TGT) cooperative learning model on the learning outcomes of VII grade students SMPN 3 Kempo academic year 2020/2021 on the material algebraic form. The type of research is pre-experimental research with one shot case study design. The research was conducted in 4 meeting for using the TGT cooperative learning and 1 meeting for the implementation of the posttest. The sample is done by purposive sampling technique, the sample was class VII-A as the experimental class which is using the TGT cooperative learning. Data collection using observation and test techniques. Instruments include: observation sheets and learning outcomes tests. The learning outcome data is used to determine how far the students understand the material being taught and the observation data is used to determine the quality of the teaching and learning process which is analyzed descriptively. The research indicator is model TGT cooperative learning, effective if the students' learning with a classical learning completeness percentage $\geq 85 \%$. Based on the results obtained 16 students who had completed their studies or equal to $88.89 \%$ and 2 students who did not complete their studies or $11.11 \%$. The results of observations teacher activities obtained $85 \%$ with good criteria, and observations students activities obtained $80 \%$ with active criteria. Based on the research results, the cooperative learning model type Teams Games Tournaments (TGT) is effective on the learning students outcomes.
\end{abstract}

Keywords: Pre-Experimental; Purposive Sampling; Posttest; Teacher Activity; Student Activity

\begin{abstract}
Abstrak
Penelitian ini bertujuan untuk mengetahui efektivitas model pembelajaran kooperatif tipe Teams Games Tournaments (TGT) terhadap hasil belajar matematika siswa kelas VII SMP Negeri 3 Kempo tahun pelajaran 2020/2021 materi bentuk aljabar. Jenis penelitian yang digunakan adalah pre-experimental dengan desain one shot case study. Penelitian ini dilaksanakan dalam 4 kali pertemuan dengan menggunakan model pembelajaran kooperatif tipe TGT dan 1 kali pertemuan dilaksanakan posttest. Penentuan sampel dilakukan dengan teknik purposive sampling, sampel adalah kelas VII-A sebagai kelas eksperimen. Pengumpulan data dengan teknik tes dan observasi. Instrument meliputi: tes hasil belajar dan lembar observasi. Data hasil belajar digunakan untuk mengetahui seberapa jauh pemahaman siswa terhadap materi yang diajarkan dan data hasil observasi digunakan untuk mengetahui kualitas proses belajar mengajar yang dianalisis secara deskriptif. Indikator penelitian yaitu model pembelajaran kooperatif tipe TGT efektif jika hasil belajar siswa dengan peresentase ketuntasan belajar klasikal $\geq 85 \%$. Berdasarkan hasil penelitian diperoleh 16 siswa dinyatakan tuntas belajarnya atau sebesar 88,89\% dan 2 siswa yang tidak tuntas belajarnya atau sebesar 11,11\%. Hasil observasi aktivitas guru diperoleh $85 \%$ dengan kriteria baik, dan observasi aktivitas siswa diperoleh 80\% dengan kriteria aktif. Berdasarkan hasil penelitian maka model pembelajaran kooperatif tipe Teams Games Tournaments (TGT) efektif terhadap hasil belajar siswa.
\end{abstract}

Kata Kunci: Pre-Experimental; Purposive Sampling; Posttest; Aktivitas Guru; Aktivitas Siswa 


\section{PENDAHULUAN}

Pendidikan adalah salah satu unsur yang penting dalam meningkatkan kualitas sumber daya manusia karena dengan menempuh pendidikan seseorang dapat memperoleh pengetahuan, pengalaman, dan keterampilan melalui suatu proses pembelajaran. Pembelajaran merupakan suatu proses pembentukan kepribadian dan pola pikir siswa, (Hadi, 2017) menegaskan bahwa "Pendidikan merupakan proses merawat, dan mengembangkan fitrah manusia, untuk menjadi baik bagi dirinya, dan positif bagi objekobjek lain diluar dirinya”.

Mata pelajaran matematika perlu diberikan kepada seluruh siswa dari SD sampai dengan perguruan tinggi agar membekali siswa untuk berpikir logis, sistematis, kritis, kreatif serta kemampuan untuk bekerjasama. Salah satu sifat matematika adalah abstrak, pembelajaran matematika di sekolah semestinya tidak hanya menekankan pada pemberian rumus-rumus, tetapi juga mengembangkan kemampuan siswa untuk menyelesaikan berbagai masalah yang berkaitan dengan kehidupan sehari-hari.

Persoalan yang terjadi saat ini, dalam pembelajaran guru sering kali menjadi pusat pembelajaran (teacher centered) dan siswa hanya menjadi objek penerima saja. Tidak hanya itu selama pandemi Covid-19 semua kegiatan dilakukan secara online, begitu juga dengan pembelajaran di satuan pendidikan. Saat ini pembelajaran daring sudah tidak awam lagi bagi siswa di SMP Negeri 3 Kempo yang juga mengikuti instruksi dari pemerintah untuk melakukan pembelajaran daring.

Berdasarkan hasil wawancara dengan guru matematika kelas VII SMP Negeri 3 Kempo, diperoleh informasi bahwa selama melakukan pembelajaran melalui daring (Whats App) guru hanya mengirimkan materi dan tugas di WA grup, tetapi tidak sedikit siswa yang juga kesekolah untuk mengambil soal dikarenakan tidak memiliki Handphone Android. Selama melakukan pembelajaran yang terjadi adalah kurangnya interaksi antara siswa dan guru maupun antar siswa, sehingga siswa meraja jenuh, bosan dan tidak semangat dalam belajar, ini berarti kualitas pembelajaran daring melalui (Whatss App) di SMP Negeri 3 Kempo sulit disesuaikan dengan keadaan siswa karena kurang memadai.

Siswa beranggapan bahwa mata pelajaran matematika merupakan pelajaran yang sulit karena siswa hanya menerima dan mengikuti penyelesaian contoh soal yang diberikan oleh guru, ditambah lagi dengan pembelajaran melalui daring membuat siswa malas mengemukakan pendapat atau bertanya tentang apa yang belum dipahami siswa kurang aktif dan cenderung membosankan. Sehingga kurangnya motivasi untuk belajar yang menyebabkan rendahnya hasil belajar siswa. Dapat dilihat dari nilai ulangan harian kelas VII SMP N 3 Kempo yang disajikan pada Tabel 1. 
Tabel 1. Nilai Rata-Rata Matematika Ulangan Harian Siswa Kelas VII SMP Negeri 3 Kempo Tahun Ajaran 2020/2021 Materi Billangan

\begin{tabular}{ccccc}
\hline No. & Kelas & $\begin{array}{c}\text { Jumlah } \\
\text { Siswa }\end{array}$ & $\begin{array}{c}\text { Nilai Rata- } \\
\text { Rata }\end{array}$ & $\begin{array}{c}\text { Ketuntasan } \\
\text { Klasikal }\end{array}$ \\
\hline 1. & VII. A & 19 & 43,72 & $0,22 \%$ \\
\hline 2. & VII. B & 19 & 45.27 & $0,16 \%$ \\
\hline
\end{tabular}

(Sumber: Data Nilai Guru Matematika SMP Negeri 3 Kempo)

Ada beberapa faktor yang mempengaruhi hasil belajar, menurut (Sudjana, 2012) hasil belajar memiliki dua faktor yang berpengaruh yaitu faktor dari dalam diri siswa dan faktor yang berasal dari luar diri siswa atau faktor lingkungan. Faktor dalam diri (internal) muncul akibat dalam diri sendiri seperti motivasi belajar, gaya belajar, kebiasaan belajar, ketekunan dan lain-lain. Sedangkan faktor dari luar (eksternal) diri siswa ialah kualitas pengajaran. Faktor-faktor tersebut harus diperhatikan jika ingin mendapat hasil belajar yang bagus atau hasil belajar yang lebih baik dari sebelumnya.

Dari penjelasan tersebut dapat diketahui bahwa ketika kualitas pembelajaran dapat dilakukan secara optimal (faktor eksternal) maka siswa akan lebih termotivasi dalam belajar (faktor internal) sehingga keluaran (output) yang didapatkan dari siswa tersebut adalah hasil belajar yang lebih baik dari sebelumnya. Untuk itu guru sebaiknya membangun motivasi belajar yang dimiliki siswa. Guru, siswa dan model pembelajaran merupakan komponen pada proses pembelajaran, agar proses pembelajaran berhasil guru harus membimbing siswa dan menggunakan model pembelajaran secara optimal. Menurut (Nurul Hikmah, 2019) Penerapan model pembelajaran yang tepat pada dasarnya bertujuan untuk menciptakan kondisi pembelajaran yang memungkinkan siswa dapat belajar secara aktif dan menyenangkan sehingga siswa dapat meraih prestasi belajar yang optimal. Dari itu diperlukan suatu model pembelajaran yang tepat salah satunya adalah pembelajaran kooperatif tipe Teams Games Tournaments (TGT).

Pembelajaran kooperatif tipe TGT merupakan model pembelajaran yang memberika kesempatan kepada siswa untuk bekerjasama dan aktif dengan sesama siswa lainnya dalam kegiatan belajar mengajar serta siswa lebih percaya diri dalam mengemukakan pendapat. (Priansa, 2017) Pembelajaran kooperatif tipe TGT diharapkan dapat memberikan motivasi atau minat siswa dalam proses pembelajaran, sehingga hasil belajar siswa terhadap pelajaran matematika akan lebih baik dari sebelumnya.

Pembelajaran dengan menerapkan model pembelajaran kooperatif tipe teams games tournaments memiliki 5 komponen yaitu: 1) Penyajian kelas/penjelasan materi yang dilakukan guru, pada kegiatan ini guru menyampaikan materi pokok yang akan dipelajari, memberikan kesempatan kepada siswa jika ada yang ingin dipertanyakan. 2) Belajar dalam kelompok/siswa dikelompokkan secara heterogen, setiap kelompok dibagikan LKS dan siswa-siswa tekun mengerjakan LKS, kegiatan ini bertujuan memperbaiki kesalahan konsep teman sekelompok dan melatih siswa percaya diri untuk mengemukakan pendapat. Kegiatan ini membuat siswa antusia bertanya kepada guru 
maupun temannya. 3) Games/permainan dengan menjawab kartu soal, kemudian guru mengarahkan siswa untuk memilih kartu soal dan menjawab pertanyaan yang sesuai dengan nomor tersebut untuk mendapatkan skor, yang dimana skor tersebut dikumpulkan pada turnamen. Jika kelompok tersebut dapat menjawab soal maka kelompok tersebut akan mendapatkan skor dan sebaliknya. 4) tournaments/pertandingan, siswa dibagi berdasarkan tingkat kemampuan tinggi, sedang dan rendah pada meja turnamen untuk menyelesaikan pertandingan dengan cara menjawab soal yang telah diberikan. 5) Penghargaan kelompok, dengan menentukan kelompok yang mendapatkan skor tertinggi dan memberikan penghargaan kepada kelompok yang tersebut (Priansa, 2017). Tim atau kelompok mendapat julukan Super Team jika rata-rata skor 50 atau lebih, Great Team apabila rata-rata mencapai 50-40 dan Good Team apabila rata-ratanya 40 kebawah.

Di SMP Negeri 3 Kempo telah melakukan pembelajaran tatap muka, ini berarti pembelajaran kooperatif tipe TGT dapat diterapkan. Maka peneliti akan melakukan penelitian dengan judul "Efektivitas Model Pembelajaran Kooperatif tipe TGT (Teams Games Tournaments) Terhadap Hasil Belajar Matematika Siswa Kelas VII SMP Negeri 3 Kempo Tahun Pelajaran 2020/2021”.

\section{METODE}

Penelitian ini dilakukan di SMP Negeri 3 Kempo semester ganjil tahun pelajaran 2020/2021, pada materi bentuk aljabar, penelitian dilakukan 5 kali pertemuan dimana 4 kali dilakukan proses pembelajaran dan 1 kali dilakukan tes akhir (post-test). Penelitian ini adalah penelitian pre-exsperimental Menurut (Emzir, 2017) penelitian pre-experimental dinamakan demikian karena mengikuti langkah-langkah dasar eksperimental, tetapi gagal memasukan kelompok kontrol.

Pendekatan dalam penelitian ini adalah kuantitatif, menggunakan strategi penelitian seperti eksperimen dan survey yang memerlukan data statistik (Sugiyono, 2019). Desain yang digunakan dalam penelitian yaitu One Shott Case Study, yang bertujuan untuk menentukan apakah ada perubahan terhadap hasil belajar setelah diberi perlakuan. Hasil belajar yang menggunakan posttest akan dijadikan patokan untuk menarik kesimpulan (Sugiyono, 2019).

Variabel dalam penelitian ini adalah variabel bebas dan terikat. Variabel bebas adalah model pembelajaran kooperatif tipe Geams Games Tournament (TGT), dan variabel terikat adalah hasil belajar matematika. Populasi dalam penelitian ini seluruh siswa kelas VII SMP Negeri 3 Kempo tahun pelajaran 2020/2021 yang terdiri dari 2 kelas. Penentuan sampel dilakukan dengan teknik sampling purposive. Sampling purposive adalah teknik penentuan sampel dengan pertimbangan tertentu (Sugiyono, 2019). Pertimbangan dipilihnya satu kelas sebagai kelas sampel, melihat keterbatasan peneliti dengan keadaan COVID-19. Sampel adalah kelas VII-A dengan jumlah 18 siswa sebagai 
kelas ekperimen yang diberikan perlakuan dengan menggunakan model pembelajaran kooperatif tipe TGT.

Instrument yang digunakan adalah soal tes uraian untuk mengukur hasil belajar siswa, sebelum tes digunakan dilakukan uji validitas isi. Sebagai pendukung dilakukan observasi aktivitas guru dan siswa untuk mengetahui proses pembelajaran tampak atau tidak tampak pada pembelajaran kooperatif tipe TGT. Instrumen soal tes uraian dilakukan uji validitas menggunakan rumus Aiken's V untuk mengetahui instrument layak atau tidak digunakan. Formula Aiken's V untuk menghitung koefisien validitas isi menurut Aiken dalam (Harmurni, 2019):

$V=\frac{\sum s}{[n(c-1)]}$

$S=r-l_{o}$

Keterangan:

$\mathrm{V}=$ indeks validitas butir

$l_{o}=$ skor penilian validitas terendah

$c=$ skor penilian validitas terting $i$

$r=$ skor yang diberikan oleh penilai

$n=$ jumlah validator

Teknik analisis data yang digunakan adalah analisis statistik deskriptif, untuk menganalisis data hasil belajar matematika siswa yang telah diperoleh. Hal ini bertujuan untuk mengetahui efektivitas dari perlakuan yang diberikan terhadap hasil belajar matematika siswa. Penilaian hasil belajar matematika siswa akan dianalisis menggunakan ketuntasan belajar klasikal. Indikator model pembelajaran kooperatif tipe TGT (Teams Games Tournaments) dikatakan efektif terhadap hasil belajar matematika siswa, jika ketuntasan belajar klasikal $\geq 85 \%$ dari seluruh siswa yang tuntas, menurut Depdikbud dalam (Trianto, 2010). Rumus menghitung ketuntasan belajar klasikal sebagai berikut:

$$
\text { ketuntasan klasika }=\frac{\text { jumlah siswa tuntas belajar }}{\text { jumlah seluruh siswa }} \times 100 \%
$$

Sebagai pendukung keterlaksanaan proses pembelajaran secara optimal dilakukan observasi aktivitas guru dan aktivitas siswa. Data yang diperoleh dari lembar observasi aktivitas guru dapat dilihat dari presentase nilai rata-rata yaitu sebagai berikut (Nurpratiwi, 2015):

$A G=\frac{\Sigma G}{\Sigma g} \times 100 \%$

Keterangan:

$A G \quad$ : Persentase nilai rata-rata

$\Sigma G \quad$ : Jumlah skor perolehan

$\Sigma g \quad$ : Skor maksimal 
Data yang diperoleh dari lembar observasi aktivitas siswa dapat dilihat dari presentase nilai rata-rata yaitu sebagai berikut (Nurpratiwi, 2015):

$A S=\frac{\Sigma S}{\Sigma s} \times 100 \%$

Keterangan:

AS : Persentase nilai rata-rata

$\Sigma S \quad$ : Jumlah skor perolehan

Is $\quad$ : Skor maksimal

\section{HASIL DAN PEMBAHASAN}

Penelitian ini dilakukan dengan tujuan untuk mengetahui efektivitas model pembelajaran kooperatif tipe Teams Games Tournaments (TGT) terhadap hasil belajar matematika aiswa kelas VII SMP Negeri 3 Kempo tahun pelajaran 2020/2021. Penelitian ini dilaksanakan pada tanggal 23 November sampai dengan 2 Desember 2020, empat kali pertemuan untuk kegiatan pembelajaran dan satu kali pertemuan untuk pelaksanaan tes akhir (posttest). Untuk setiap proses pembelajaran dari pertemuan pertama sampai dengan pertemuan keempat, saat proses pembelajaran berlangsung dilakukan observasi aktivitas guru dan siswa. Observasi diamati langsung oleh observer (guru mata pelajaran matematika). Pada pertemuan kelima siswa diberikan tes akhir (posttest) untuk mengevaluasi pengetahuan siswa dan melihat hasil belajar matematika siswa materi bentuk aljabar.

Uji instrument yang digunakan adalah uji validitas isi yang dilakukan oleh dosen pendidikan matematika Universitas Mataram. Dari uji instrument didapat hasil bahwa instrument layak digunakan.

\subsection{Hasil Uji Instrument}

Soal posttest divalidasi dengan membuat lembar validasi instrumen untuk mendapatkan saran dan perbaikan dari ahli sebagai validator. Hasil validasi isi dianalisis menggunakan Aiken's V, dapat diihat dari Tabel 2.

Tabel 2. Hasil Analisis Uji Instrumen

\begin{tabular}{ccc}
\hline Aspek yang dinilai & Indeks validitas & Keterangan \\
\hline Materi & 0,84 & Baik \\
\hline Konstruk & 0,88 & Sangat baik \\
\hline Bahasa & 0,90 & Sangat baik \\
\hline
\end{tabular}

Berdasarkan hasil tersebut diketahui dari ketiga aspek yang dinilai memiliki indeks validitas tinggi dengan keterangan baik dan sangat baik, ini berarti trument layak untuk digunakan. 


\subsection{Statistik Deskriptif}

Analisis statistik deskriptif digunakan untuk menganalisis data hasil belajar matematika siswa yang telah diperoleh. Hal ini bertujuan untuk mengetahui efektivitas dari perlakuan yang diberikan terhadap hasil belajar matematika siswa.

\subsubsection{Ketuntasan Belajar Klasikal}

KKM yang ditetapkan SMP Negeri 3 Kempo sebesar $\geq 65$, nilai posttest yang telah diperoleh dapat dilihat pada Tabel 3 .

Tabel 3. Hasil Analisis Ketuntasan Belajar Klasikal

\begin{tabular}{ccc}
\hline Perolehan & Frekuensi & Persentase \\
\hline Jumlah siswa yang tidak tuntas & 2 & $11,11 \%$ \\
\hline Jumlah siswa yang tuntas & 16 & $88,89 \%$ \\
\hline Jumlah & 18 & $100 \%$ \\
\hline
\end{tabular}

Dilihat dari keterangan tersebut, diperoleh sebanyak 16 siswa yang tuntas belajarnya atau sebesar $88,89 \%$ (ketuntasan belajar klasikal). Sedangkan untuk siswa yang tidak tuntas pada materi bentuk aljabar semester 1 kelas VII-A dengan model pembelajaran kooperatif tipe TGT yaitu sebanyak 2 siswa atau sebesar $11,11 \%$ yang tidak tuntas.

Hasil ini menunjukkan bahwa indikator dari penelitian ini telah tercapai sesuai dengan standar yang telah ditetapkan. Dimana indikator penelitian yang ditetapkan adalah hasil belajar matematika siswa dengan persentase ketuntasan belajar klasikal $\geq 85 \%$.

\subsubsection{Observasi Aktivitas Guru dan Siswa}

Observasi aktivitas guru dilakukan untuk melihat keterlaksanaan pada proses pembelajaran secara optimal, yang diamati oleh observer (guru mata pelajaran matematika) dengan lemar observasi aktivitas guru. Adapun analisi data hasil observasi aktivitas guru dapat dilihat pada Tabel 4 .

Tabel 4. Analisis Observasi Aktivitas Guru

\begin{tabular}{cccccc}
\hline Pertemuan & $\begin{array}{c}\text { Jumlah } \\
\text { skor }\end{array}$ & $\begin{array}{c}\text { Skor } \\
\text { maksimum }\end{array}$ & Persentase & Kriteria \\
\cline { 1 - 1 } Pertemuan I & 40 & 54 & $74 \%$ & Baik \\
\hline Pertemuan II & 46 & 54 & $85 \%$ & Baik \\
\hline Pertemuan III & 48 & 54 & $89 \%$ & sangat Baik \\
\hline Pertemuan IV & 50 & 54 & $93 \%$ & sangat Baik \\
\hline Total & 184 & 216 & $85 \%$ & Baik \\
\hline
\end{tabular}

Berdasarkan hasil analisis data observasi aktivitas guru secara keseluruhan persentase nilai rata-rata adalah $85 \%$ dalam kriteria baik. Adanya perubahan aktivitas disetiap 
pertemuan guru melakukan pendekatan dengan siswa, karena guru dan siswa belum ada pendekatan yang maksimal. Dari hasil observasi aktivitas guru diketahui bahwa keterlaksaan pembelajaran kooperatif tipe TGT tampak atau telah dilaksanakan, serta guru dapat dikatakan tepat dalam mengatur waktu dan melaksanakan tindakan sesuai dengan rencana pembelajaran. Ini berarti proses pembelajaran kooperatif tipe TGT telah dilakukan secara optimal atau berjalan dengan baik.

Hasil observasi aktivitas guru tersebut sejalan dengan hasil observasi aktivitas siswa terhadap proses pembelajaran yang dilaksanakan. Aktivitas siswa diamati oleh observer (guru mata pelajaran matematika) dengan lembar observasi aktivitas siswa. Adapun hasil analisis observasi aktivitas siswa dapat dilihat dalam Tabel 5.

Tabel 5. Analisis Observasi Aktivitas Siswa

\begin{tabular}{ccccc}
\hline Pertemuan & \multirow{2}{*}{$\begin{array}{c}\text { Jumlah } \\
\text { skor }\end{array}$} & $\begin{array}{c}\text { Skor } \\
\text { maksimal }\end{array}$ & Persentase & Kriteria \\
\cline { 1 - 1 } ke-n & 35 & 48 & $73 \%$ & Aktif \\
\hline Pertemuan I & 37 & 48 & $77 \%$ & Aktif \\
\hline Pertemuan III & 40 & 48 & $83 \%$ & Aktif \\
\hline Pertemuan IV & 42 & 48 & $88 \%$ & Sangat aktif \\
\hline Total & 154 & 192 & $80 \%$ & Aktif \\
\hline
\end{tabular}

Berdasarkan hasil analisis data observasi aktivitas siswa secara keseluruhan persentase nilai rata-rata aktivitas siswa selama proses pembelajaran adalah $80 \%$ berada pada kriteria aktif. Hal tersebut membuktikan bahwa penerapan model pembelajaran kooperatif tipe TGT menjadikan siswa aktif atau termotivasi pada kegiatan pembelajaran sehingga daya serap siswa dalam mengimplementasikan dan mengembangkan konsep yang sudah diperoleh sesuai dengan aspek kognitif siswa. Siswa bekerja secara kelompok dan saling berinteraksi sehingga menjadikan hubungan yang baik antar siswa. Seperti yang dikemukakan oleh Ibrahim dkk dalam (Trianto, 2010) bahwa belajar kooperatif dapat meningkatkan hubungan yang lebih baik antar siswa serta dapat mengembangkan kemampuan akademik siswa dan secara aktif bekerja sama meyelesaikan suatu permasalahan.

Berdasarkan uraian diatas menunjukkan bahwa pembelajaran kooperatif tipe TGT telah dilakukan secara optimal (faktor eksternal) keterlaksanaan proses pembelajaran yang dilakukan guru tampak atau telah dilaksanakan dari aktivitas guru, maka siswa lebih aktif dan termotivsi (faktor internal) pada saat kegiatan pembelajaran dari aktivitas siswa, sehingga keluaran (output) yang didapat dari siswa adalah hasil belajar yang optimal. Dari nilai tes akhir (posttest) hasil belajar siswa menunjukkan bahwa ketuntasan belajar klasikal dalam kelas VIIA telah tercapai sesuai indikator. 


\section{PENUTUP}

Berdasarkan hasil dan pembahasan pada penelitian, dapat disimpulkan bahwa model pembelajaran kooperatif tipe Teams Games Tournaments (TGT) efektif terhadap hasil belajar matematika siswa kelas VII SMP Negeri 3 Kempo tahun pelajaran 2020/2021.

\section{REKOMENDASI}

a. Pembelajaran kooperatif tipe Teams Games Tournaments (TGT) sebaiknya dilakukan siswa semangat dalam belajar, dengan adanya pembelajaran TGT ini siswa dapat termotivasi dalam proses pembelajaran.

b. Siswa belum terbiasa dengan pembelajaran kooperatif tipe TGT sehingga guru melakukan beberapa perbaikan terhadap aspek yang dinilai.

\section{REFERENCES}

Emzir. (2017). Metodologi Penelitian Pendidikan: Kuantitatif dan Kualitataif. Depok: PT Raja Grafindo Persada.

Hadi, L. S. (2017). Pendidikan Dialog Idealitas Vs Realitas. Lombok Barat: CV Elhikam Press Lombok.

Harmurni, L. (2019). Instrumen Penilaian \& Validasinya. Jawa Timur : Uwais Inspirasi Indonesia.

Nurpratiwi, R. T. (2015). Peningkatan Aktivitas dan Prestasi Belajar Siswa Melalui Metode Picture and Picture Dengan Media Audio Visual Pada Mata Pelajaran Geografi di Kelas XI IPS 2 SMA Negeri 1 Bantarkawung. Geoedukasi, $I V(2), 4$.

Nurul Hikmah, S. S. (2019). Pelatihan Penyusunan Perangkat Pembelajaran Matematika Berbasis Lesson Study di MTs Darul Qur;an Bengkel. Pendidikan dan Pengabdian Masyarakat, 2(4), 438.

Priansa, D. J. (2017). Pengembangan Strategi \& Model Pembelajaran. Bandung: CV Pustaka Setia.

Sudjana, N. (2012). Penilaian Hasil Proses Belajar Mengajar. Bandung: Rosdakarya.

Sugiyono. (2019). Metode Penelitian Kuantitatif Kualitatif dan R\&D. Bandung: Alfabeta.

Trianto. (2010). Mendesain Model Pembelajaran Inovatif-Progresif . Jakarta: Kencana. 